\title{
Reduced Organic Carbon Content during the Evolvement of Calcareous Soils in Karst Region
}

\author{
Hui Yang ${ }^{1,2} \mathbb{D}$, Yincai Xie ${ }^{1,2}$, Tongbin Zhu ${ }^{1,2, *}$ and Mengxia Zhou ${ }^{1}$ \\ 1 Karst Dynamics Laboratory, MNR and Guangxi, Institute of Karst Geology, CAGS, Guilin 541004, China; \\ yanghui@mail.cgs.gov.cn (H.Y.); xieyincai@mail.cgs.gov.cn (Y.X.); mengxia.zhou95@gmail.com (M.Z.) \\ 2 International Research Centre on Karst, Under the Auspices of UNESCO, Guilin 541004, China \\ * Correspondence: zhutongbin@gmail.com; Tel.: +86-773-5837840; Fax: +86-773-5837845
}

\section{check for}

updates

Citation: Yang, H.; Xie, Y.; Zhu, T.; Zhou, M. Reduced Organic Carbon Content during the Evolvement of Calcareous Soils in Karst Region. Forests 2021, 12, 221. https:// doi.org/10.3390/f12020221

Academic Editor: Gerrit Angst

Received: 28 December 2020

Accepted: 11 February 2021

Published: 14 February 2021

Publisher's Note: MDPI stays neutral with regard to jurisdictional claims in published maps and institutional affiliations.

Copyright: (c) 2021 by the authors. Licensee MDPI, Basel, Switzerland. This article is an open access article distributed under the terms and conditions of the Creative Commons Attribution (CC BY) license (https:// creativecommons.org/licenses/by/ $4.0 /)$.
Abstract: Understanding the changes in soil organic carbon (SOC) storage is important for accurately predicting ecosystem $\mathrm{C}$ sequestration and/or potential C losses, but the relevant information, especially for the evolvement of calcareous soil is limited in karst regions. Three calcareous soils with different evolvement intensities were sampled from an evergreen broadleaved forest in the subtropical region of southwest of China to investigate the changes in different SOC fractions and microbial communities. The results showed that: (1) The contents of SOC, dissolved organic carbon (DOC), mineral protected organic carbon (MOC), and recalcitrant organic carbon (ROC) significantly decreased with increasing evolvement intensity of calcareous soil, but $\mathrm{pH}$ and the chemical composition of SOC, including Alkyl C, O-alkyl C, Aromatic C, and Carbonyl C, did not significantly change, suggesting that various $\mathrm{SOC}$ fractions synergistically decrease with the evolvement of calcareous soil. (2) The evolvement of calcareous soil had a substantial negative effect on total phospholipid fatty acids (PLFA), bacteria (i.e., Gram positive bacteria and Gram negative bacteria), fungi, and actinomycetes, but did not affect the ratio of fungi to bacteria. This result supported the conclusion that various SOC fractions were synchronously loss with the evolvement of calcareous soil. (3) Results from the multivariate statistical analysis showed a significant correlation between SOC fractions (including SOC, DOC, MOC, and ROC) and soil base cations, mainly calcium (Ca), iron $(\mathrm{Fe})$, and aluminum (Al). This strengthens the fact that SOC stability largely depends on the complex relationship between organic matter and mineral composition in soil. Taken together, the reduction of SOC during the evolvement of soil in the karst areas accords with some mechanisms of previous studies (e.g., microbial composition and soil geochemistry), and also has its own unique characteristics (e.g., the relative contribution of carbons to chemical shift regions of CPMAS ${ }^{13} \mathrm{C}$-NMR spectra and F:B ratio).

Keywords: soil organic carbon fractions; mineral protected organic carbon; calcareous soil; microbial community; soil evolvements

\section{Introduction}

Soil organic matter (SOM) is the core of soil quality, which is important to soil fertility, sustainable agricultural systems, climate change, and many other factors related to the survival and development of the earth and human beings [1]. Soils store climatically significant amounts of carbon (C) as SOM, which is about 2.3 times and 3.5 times greater than that in atmospheric $\mathrm{CO}_{2}$ and all living terrestrial plants [2]. The $\mathrm{C}$ sequestration in $\mathrm{SOM}$ is an effective atmospheric $\mathrm{CO}_{2}$ capture strategy [3]. SOM decomposition is one of the key ways for soil to release $\mathrm{CO}_{2}$ into the atmosphere, and then it has a significant impact on global climate change. Decomposition of SOM depends on soil environmental conditions and the accessibility of organic compounds to the decomposer community [4]. Considering the role of soil organic carbon (SOC) storage, many soil types such as Cambosols [5], permafrost soil [4], and Oxisols [6] have been widely investigated. However, these studies were mainly conducted in non-karst regions, but the relevant studies are limited in karst regions. 
Karst accounts for $12 \%$ of the world's total land area [7], and China has approximately 3.44 million $\mathrm{km}^{2}$ of karst areas, including buried, covered, and exposed carbonate rock areas, accounting for $15.6 \%$ of all karst areas in the world [8]. Karstification has a profound impact on global change. The formation of carbonate rocks has a dramatic sink effect on atmospheric $\mathrm{CO}_{2}$ throughout geological time [9]. Calcareous soil in karst regions is the product of dissolution and weathering of carbonate rocks [10,11]. Previous studies found higher SOC content in calcareous soil in karst region than other soils in non-karst regions at the same latitude [12]. Thus, calcareous soils in karst regions are considered to be $\mathrm{C}$ storage at the global scale. Noticeably, due to high spatial heterogeneity in karst regions, there were many types of calcareous soil, such as black calcareous soil (BLCS), brown calcareous soil (BRCS), and red calcareous soil (RCS) [13], which represent different evolvement intensities of calcareous soils. The SOC pools in different calcareous soils are not be evaluated systematically. During the evolvement of calcareous soil, the physicochemical properties of the soil, such as structure, SOC adsorption-desorption processes, and nutrient availability, obviously change, which can significantly influence SOC fractions and SOC dynamics. In addition, calcareous soil developed on carbonate rock is characterized by high $\mathrm{pH}$ and calcium (Ca) materials in karst regions [14], which may lead to the obvious differences in the SOC fraction compared to other soil types. The high dose Ca easily stabilizing karst SOM might result in the low decomposing rate of SOM [15]. As an example, Yang et al. (2016) [16] recently established that the concentration of SOC when developed on Ca rich, calcareous lithology contained nearly 2 folds higher than their acidic counterparts in alpine grassland soils in the Neotropical alpine ecosystem. Similarly, Yang et al. (2019) [14] demonstrated that Ca was the most important variable for C, N, and P stoichiometry calcareous soils of karst graben basins. Whittinghill and Hobbie (2012) indicated that both polyvalent cation concentration and $\mathrm{pH}$ likely influence microbial activity in tundra soils [17]. However, it remains unclear how SOC in different soil fractions changes during the evolvement of calcareous soil.

SOC decomposition is a process involving complex interactions of multiple factors and mechanisms, among which SOC quality, microbial properties, and environmental drivers are three primary sets $[18,19]$. Despite all the work conducted so far, our understanding of the determinants of calcareous soil decomposition is still limited by the following three aspects. First, SOC is a mixture of pools which can be divided into labile and recalcitrant SOC fractions based on the relative susceptibility to biological decomposition [20]. Given the different turnover rate and stabilization mechanism of different SOC fractions, the response of dynamics of labile and recalcitrant SOC during the evolvement of calcareous soil may be substantially different. Furthermore, changes in SOC fractions could influence both nutrient supply and soil $C$ sequestration, it is necessary to fractionate and quantify the labile and recalcitrant fractions, which would facilitate our understanding of factors influencing SOC dynamics [21]. However, relatively few studies have attempted to investigate different fractions of SOC in response to calcareous soil evolvement.

Second, there is increasing evidence that SOC stability is largely dependent on the complex relationship between organic matter and mineral composition [22,23]. The adsorption of SOC to mineral bound by ligand exchange [24], polyvalent cation bond bridges [25], and complexation of organic ligand by free cation, including calcium ion $\left(\mathrm{Ca}^{2+}\right)$, aluminum ion $\left(\mathrm{Al}^{3+}\right)$, iron ion $\left(\mathrm{Fe}^{3+}\right)$, and their mineral forms [15], is the primary chemical protection mechanism of SOC persistence. Previous studies have shown that the contents of base cations decrease with the evolvement of calcareous soil [26]. However, it remains unknown that how base cations affect SOC in different calcareous soils.

Third, the incomplete knowledge about the patterns of soil microbial communities in calcareous soil with different evolvement intensities limits our ability to understand the importance of microbial communities in regulating SOC decomposition. Microbial communities can greatly affect soil $\mathrm{N}$ and C cycling [27] and thereby alter SOC content of calcareous soil. The utilization of organic matter by soil microorganisms varies with different life history strategies. For instance, K-strategy microorganisms (e.g., fungi) mainly 
decompose recalcitrant SOC, while r-strategy microbes (such as bacteria) prefer to decompose some labile organic carbon [28]. Similar to fungi, actinomycete bacteria also produce lignin-degrading enzymes and can break down relatively recalcitrant substrates [28].

We assumed that (1) the SOC content in calcareous soils decreased with the evolvement of calcareous soil due to the depletion of base cations; (2) the microbial composition, mainly fungi, bacteria, and actinomycete bacteria, have close relationship with SOC and SOC fractions with the evolvement of calcareous soil, because lower microbial biomass would suppress microbial decomposition of litters and reduce the input of organic matter. To verify our hypotheses, BLCS, BRCS, and RCS, which represent the early, middle, and late evolvement stage of calcareous soil, respectively, were collected in a subtropical karst region of southwest of China. We explored the responses of soil chemistry, microbial community as assessed by phospholipid fatty acid (PLFA) analysis, and C stock in three soil fractions, including dissolved organic carbon (DOC), mineral protected organic carbon (MOC), and recalcitrant organic carbon (ROC). The result of the present study can contribute to a better understanding and prediction of soil $\mathrm{C}$ dynamics of calcareous soil in karst areas.

\section{Materials and Methods}

\subsection{Study Area and Sample Collection}

The study site was located in Maocun karst experimental site $\left(25^{\circ} 10^{\prime} 11^{\prime \prime}-25^{\circ} 12^{\prime} 30^{\prime \prime} \mathrm{N}\right.$ and $\left.110^{\circ} 30^{\prime} 00^{\prime \prime}-110^{\circ} 33^{\prime} 45^{\prime \prime} \mathrm{E}\right), 30 \mathrm{~km}$ to the southeast of Guilin city, Guangxi province, southwest of China (Figure 1). It is characterized by a typical karst landscape and the topography is dominated by peak cluster depressions. This region has a typical subtropical monsoon climate with an average annual temperature of $18.6^{\circ} \mathrm{C}$ and annual precipitation of $1980 \mathrm{~mm}$ [29].

Soil samples were collected from a peak cluster with an elevation of approximately $200 \mathrm{~m}$ asl and the slope between 200 and 450, including three typical calcareous soils with different soil evolvement stages, among which BLCS, BRCS, and RCS represent the early, middle, and late evolvement stages of calcareous soils, respectively. The details of the soil samples were shown in Table S1. The BLCS was Leptosols (calcareous soil) according to the FAO World Reference Base for Soil Resources [30], the BRCS was Luvisols, and RCS was Ferrisols. All soils were developed from thick dolomite of Donggangling Formation.

Field sampling was conducted according to a standardized sampling method [31]. Three representative sites for BLCS, BRCS, or RCS were sampled, respectively, to result in nine soil samples. The distance between sites was beyond $50 \mathrm{~m}$. At each site, we set up five $1 \mathrm{~m} \times 1 \mathrm{~m}$ quadrats, and soil samples $(0-15 \mathrm{~cm})$ were randomly collected using soil corers ( $5 \mathrm{~cm}$ in diameter) at 5-10 points within each quadrat depending on the actual distribution of calcareous soils, especially BLCS, which is mainly distributed in the cracks, and then all soils were mixed into one composite sample for each site. Fresh soil was passed through a $2 \mathrm{~mm}$ sieve, and stones and roots were removed to improve soil homogeneity.

\subsection{Laboratory Analysis}

Soil $\mathrm{pH}$ was determined at a 1:2.5 $(w / v)$ soil/water ratio by a digital millivolt $\mathrm{pH}$ Meter-2 (DMP-2 mV/pH) detector (Quark Ltd., Nanjing, China). After removing carbonate using a pretreatment with $1 \mathrm{~mol} \mathrm{L-1} \mathrm{HCl}, \mathrm{SOC}$ and total $\mathrm{N}(\mathrm{TN})$ was analyzed by a Sercon SL C/N Elemental Analyzer. Cation exchange capacity (CEC) was analyzed by the ammonium acetate method at $\mathrm{pH}$ 7.0, and extracts were analyzed for exchangeable cations including exchangeable calcium (Caex), exchangeable aluminum (Alex), and exchangeable iron (Feex) by ICP-AES [32]. The free Fe and Al oxides (noted as Fed and Ald, respectively) were extracted with the Citrate Bicarbonate Dithionite system and were measured using ICP-AES [33]. The contents of aluminum oxide $\left(\mathrm{Al}_{2} \mathrm{O}_{3}\right)$, silicon dioxide $\left(\mathrm{SiO}_{2}\right)$, and ferric oxide $\left(\mathrm{Fe}_{2} \mathrm{O}_{3}\right)$ in soil were determined using total X-ray fluorescence (XRF) spectroscopy. 


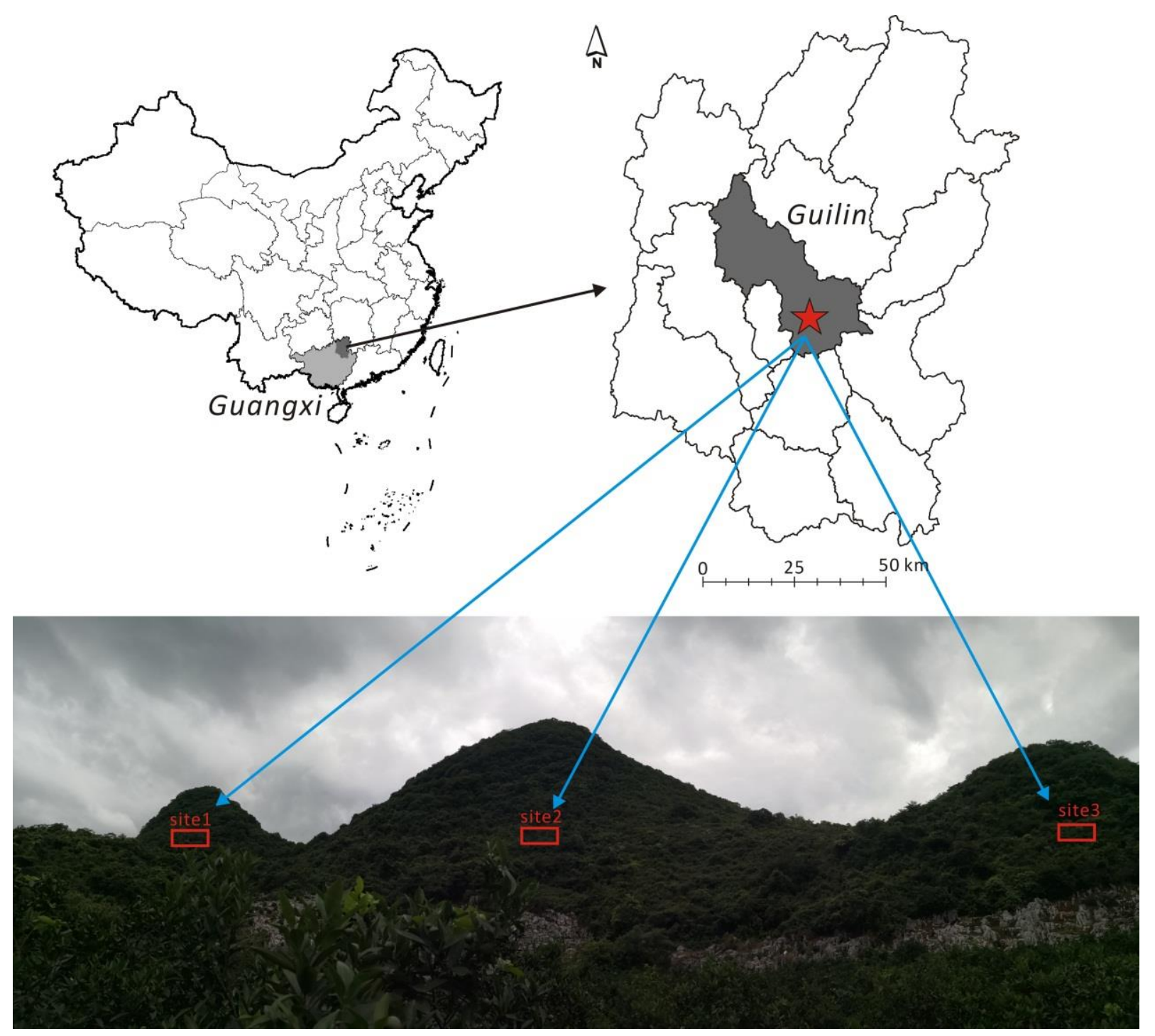

Figure 1. Location of sampling sites in Guilin county, Guangxi Zhuang Autonomous Region.

\subsubsection{Fractions of Soil Organic $C$}

The content of stable organic $C$ was estimated as the content of residual organic $C$ (ROC) left after treatment with $\mathrm{NaOCl}[34,35]$. The procedures and processes of separation and quantification of ROC and MOC were reported in Mikutta et al. [35]. It should be noted that the extraction by $\mathrm{NaOCl}$ refers to stable organic $\mathrm{C}$ and subsequently released by HF refers to MOC, whereas organic $C$ not released by HF represents ROC. DOC was determined by deionized water $(1: 5(w / v)$ soil/water ratio), and extracts were analyzed by multi N/C 3100 analyzer (Analytik Jena, Jena, Germany).

\subsubsection{Chemical Characterization of Soil Organic $C$}

We obtained solid-state nuclear magnetic resonance (NMR) spectra of bulk materials from all nine soil samples using a FT MR system (AVANCE III HD 400 Bruker BioSpin Corp., Ettlingen, Germany) using the cross polarization magic angle spinning (CPMAS) technique with $13 \mathrm{C}$ signal at $75.57 \mathrm{MHz}$, magic angle spinning of $5 \mathrm{kHz}$, a contact time of $2 \mathrm{~ms}$, and a pulse interval of $34 \mathrm{~s}$ [36]. The NMR spectrum was divided into four chemical shift regions representative of the major type of carbon present in the samples following Wagai et al. (2013) [36]: 0-45 ppm (Alkyl C), 45-110 ppm (O-alkyl C), 110-160 ppm 
(Aromatic C), 160-220 ppm (Carbonyl C). The total signal intensity and the proportion contributed by each $C$ type were determined by integration of the spectral regions.

\subsubsection{PLFA Extraction and Analysis}

We obtained soil microbial community of bulk materials from all nine soil samples using by assessing soil phospholipid fatty acids (PLFA) using a gas chromatograph (6890, Agilent, Santa Clara, CA, USA) $[37,38]$. The procedures and processes of separation and quantification of PLFA were reported in Chen et al. [39].

\subsection{Statistical Analysis}

Differences in physical and chemical characteristics, soil microbial community, relative contribution of carbons to chemical shift regions of CPMAS ${ }^{13} \mathrm{C}-\mathrm{NMR}$ spectra and various SOC fractions were assessed by one-way analysis of variance (ANOVA), followed by Duncan's post hoc tests. Principal components analysis (PCA) was used to analyze soil microbial community and soil base cations with the calcarous soil evolvement intensities. Pearson correlation analysis was used to address the relationships among SOC fractions and soil base cations.

\section{Results}

\subsection{Soil Physico-Chemical Properties}

The $\mathrm{SiO}_{2} / \mathrm{Al}_{2} \mathrm{O}_{3}$ ratio (Sa) and $\mathrm{SiO}_{2} /\left(\mathrm{Al}_{2} \mathrm{O}_{3}+\mathrm{Fe}_{2} \mathrm{O}_{3}\right)$ ratio (Saf) in soil decreased significantly, while Fed/Fet increased significantly as BLCS evolved to RCS. As the evolvement of calcareous soil, SOC and TN contents were significantly reduced $(p<0.05)$, but pH did not change $(p>0.05)$. Meanwhile, as the evolvement of calcareous soil, the contents of $\mathrm{Ca}, \mathrm{Mg}, \mathrm{Ca}_{\mathrm{ex}}, \mathrm{Al}_{\mathrm{ex}}$, and $\mathrm{Fe}_{\mathrm{ex}}$, and CEC significantly decreased, with the lowest in RCS, but the contents of $\mathrm{Fe}_{\mathrm{d}}$ and $\mathrm{Al}_{\mathrm{d}}$ significantly increased, with the largest in RCS (Table 1).

Table 1. Physical and chemical characteristics in black calcareous soils (BLCS), brown calcareous soils (BRCS), and red calcareous soils (RCS).

\begin{tabular}{|c|c|c|c|c|}
\hline & Parameter & BLCS & BRCS & RCS \\
\hline \multirow{6}{*}{ Soil quality } & $\mathrm{SOC}\left(\mathrm{gC} \mathrm{kg}^{-1}\right)$ & $233 \pm 62.6 \mathrm{a}$ & $60.4 \pm 9.72 b$ & $13.7 \pm 0.83 b$ \\
\hline & $\mathrm{TN}\left(\mathrm{g} \mathrm{N} \mathrm{kg}^{-1}\right)$ & $19.9 \pm 4.80 \mathrm{a}$ & $5.41 \pm 0.72 b$ & $1.69 \pm 0.03 b$ \\
\hline & $\mathrm{C} / \mathrm{N}$ & $11.6 \pm 0.39 a$ & $11.1 \pm 0.36 \mathrm{a}$ & $8.10 \pm 0.61 b$ \\
\hline & $\operatorname{CEC}\left(\mathrm{cmol} \mathrm{kg}^{-1}\right)$ & $56.6 \pm 8.58 \mathrm{a}$ & $28.4 \pm 2.36 \mathrm{~b}$ & $14.8 \pm 0.69 c$ \\
\hline & $\mathrm{pH}$ & $7.20 \pm 0.05 \mathrm{a}$ & $7.14 \pm 0.11 \mathrm{a}$ & $7.13 \pm 0.11 \mathrm{a}$ \\
\hline & WHC (\%) & $165.62 \pm 30.43 \mathrm{a}$ & $106.09 \pm 2.9 \mathrm{~b}$ & $88.03 \pm 6.96 b$ \\
\hline \multirow{4}{*}{ Nutrient elements } & $\mathrm{Ca}\left(\mathrm{g} \mathrm{kg}^{-1}\right)$ & $58.4 \pm 13.1 \mathrm{a}$ & $18.8 \pm 12.9 \mathrm{~b}$ & $5.72 \pm 3.41 b$ \\
\hline & $\operatorname{Mg}\left(\mathrm{g} \mathrm{kg}^{-1}\right)$ & $19.9 \pm 1.00 \mathrm{a}$ & $19.2 \pm 3.89 \mathrm{a}$ & $11.9 \pm 1.18 b$ \\
\hline & $\mathrm{K}\left(\mathrm{g} \mathrm{kg}^{-1}\right)$ & $6.55 \pm 0.80 \mathrm{a}$ & $5.94 \pm 0.70 \mathrm{a}$ & $7.09 \pm 0.25 \mathrm{a}$ \\
\hline & $\mathrm{P}\left(\mathrm{mg} \mathrm{kg}^{-1}\right)$ & $2992 \pm 751 \mathrm{a}$ & $1206 \pm 239 b$ & $807 \pm 59.2 b$ \\
\hline \multirow{11}{*}{ Weathering indices } & $\mathrm{Fe}\left(\mathrm{g} \mathrm{kg}^{-1}\right)$ & $56.0 \pm 12.0 \mathrm{c}$ & $81.4 \pm 6.59 \mathrm{~b}$ & $106 \pm 3.95 a$ \\
\hline & $\mathrm{Al}\left(\mathrm{g} \mathrm{kg}^{-1}\right)$ & $65.1 \pm 23.7 c$ & $128 \pm 10.7 b$ & $171 \pm 2.14 \mathrm{a}$ \\
\hline & Free Fe $\left(\mathrm{g} \mathrm{kg}^{-1}\right)$ & $23.4 \pm 7.98 c$ & $44.2 \pm 7.73 b$ & $69.9 \pm 5.02 \mathrm{a}$ \\
\hline & Free $\mathrm{Al}\left(\mathrm{g} \mathrm{kg}^{-1}\right)$ & $4.79 \pm 1.50 c$ & $8.19 \pm 1.79 b$ & $13.3 \pm 0.28 \mathrm{a}$ \\
\hline & $\mathrm{Ca}_{\mathrm{ex}}\left(\mathrm{g} \mathrm{kg}^{-1}\right)$ & $4.31 \pm 1.72 \mathrm{a}$ & $0.74 \pm 0.65 b$ & $0.15 \pm 0.16 b$ \\
\hline & $\mathrm{Al}_{\mathrm{ex}}\left(\mathrm{mg} \mathrm{kg}^{-1}\right)$ & $39.8 \pm 17.0 \mathrm{a}$ & $5.25 \pm 1.95 b$ & $1.43 \pm 0.60 \mathrm{~b}$ \\
\hline & $\mathrm{Fe}_{\mathrm{ex}}\left(\mathrm{mg} \mathrm{kg}^{-1}\right)$ & $32.6 \pm 11.0 \mathrm{a}$ & $2.39 \pm 0.77 b$ & $1.04 \pm 0.98 b$ \\
\hline & $\mathrm{Si}\left(\mathrm{g} \mathrm{kg}^{-1}\right)$ & $202 \pm 4.80 \mathrm{~b}$ & $221 \pm 6.69 \mathrm{a}$ & $206 \pm 1.80 \mathrm{~b}$ \\
\hline & $\mathrm{Fe}_{\mathrm{d}} / \mathrm{Fe}_{\mathrm{t}}$ & $0.41 \pm 0.05 c$ & $0.54 \pm 0.05 b$ & $0.66 \pm 0.03 a$ \\
\hline & $\mathrm{Sa} \mathrm{SiO}_{2} / \mathrm{Al}_{2} \mathrm{O}_{3}$ & $6.44 \pm 1.95 \mathrm{a}$ & $3.33 \pm 0.35 b$ & $2.32 \pm 0.01 \mathrm{~b}$ \\
\hline & Saf $\mathrm{SiO}_{2} /\left(\mathrm{Al}_{2} \mathrm{O}_{3}+\mathrm{Fe}_{2} \mathrm{O}_{3}\right)$ & $4.47 \pm 1.19 \mathrm{a}$ & $2.55 \pm 0.25 b$ & $1.79 \pm 0.01 \mathrm{~b}$ \\
\hline
\end{tabular}

WHC, water holding capacity; $\mathrm{CEC}$, cation exchangeable capacity; $\mathrm{Fe}_{\mathrm{d}} / \mathrm{Fe}_{\mathrm{t}}=$ Free iron $\left(\mathrm{Fe}_{\mathrm{d}}\right) /$ the total iron content $\left(\mathrm{Fe}_{\mathrm{t}}\right)$; $\mathrm{Ca}_{\mathrm{ex}}, \mathrm{Exchangeable}$ $\mathrm{Ca}^{2+} ; \mathrm{Al}_{\mathrm{ex}}$, Exchangeable $\mathrm{Al}^{3+} ; \mathrm{Fe}_{\mathrm{ex}}$, Exchangeable $\mathrm{Fe}^{3+} ; \mathrm{BLCS}, \mathrm{BRCS}$, and RCS represent black calcareous soils, brown calcareous soils, and red calcareous soils, respectively. Different lowercase letters in the same row denote significant difference at $p<0.05$ level among different calcareous soils. 


\subsection{Soil Microbial Community Composition}

The abundances of total PLFA, bacteria mainly containing Gram positive (GP) and Gram negative (GN) decreased with the evolvement intensities of calcareous soil (Figure 2a, Figure S1a-c). In addition, the abundances of fungi (Figure 2b), arbuscular mycorrhiza fungi (AMF; Figure S1d), and actinomycetes (Figure S1e) also decreased significantly as the evolvement of calcareous soil, but the ratios of fungi:bacteria (F:B) and GP:GN did not change (Figure 2c, Figure S1f). The PCA analysis showed that microbial community composition (Figure S2) was clearly different between RCS and the other two calcareous soils (which were similar between BLCS and BRCS).
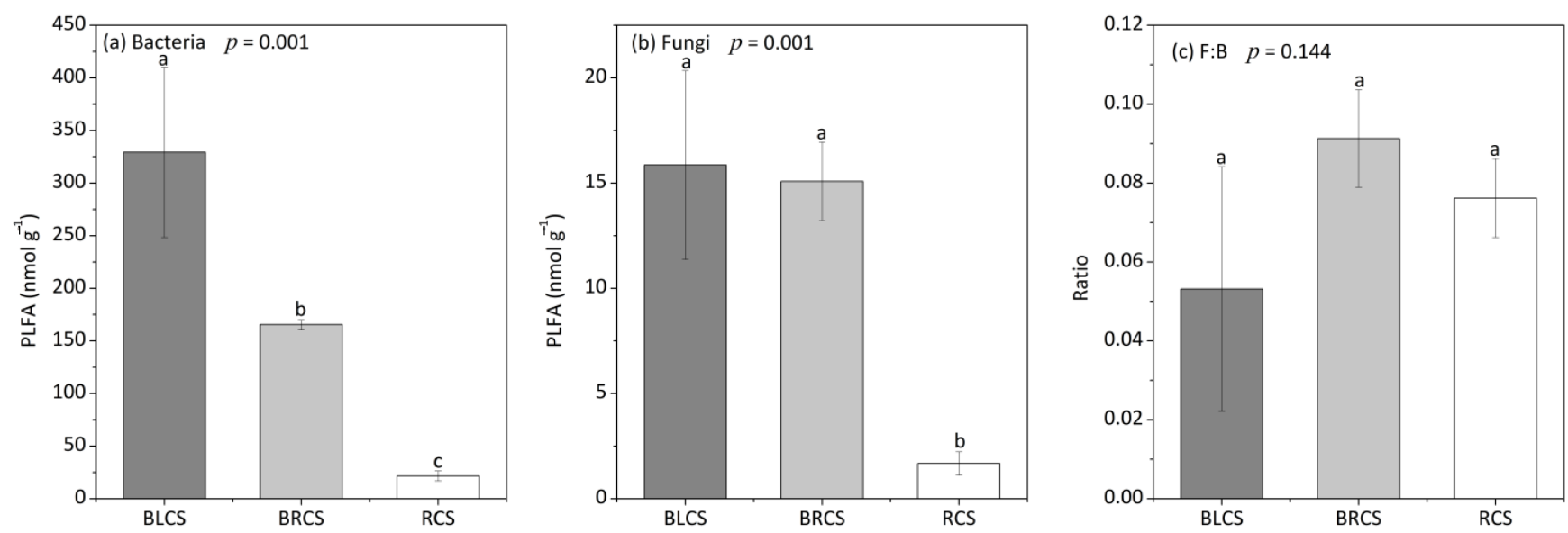

Figure 2. Effects of soil evolvement of calcareous soil on the concentrations of bacterial phospholipid fatty acid (PLFA) (a), fungal PLFA (b), and the fungi to bacteria ratio (c) in the subtropical karst area of southwest China. Values are means with standard error (SE), $n=3$. Different lowercase letters denote significant difference at $p<0.05$ level among different calcareous soils. BLCS, BRCS, and RCS represent black calcareous soil, brown calcareous soil, and red calcareous soil, respectively, the same below.

\subsection{The Changes in Soil Organic C during the Evolvement of Calcareous Soil}

The DOC content decreased significantly from $55.4 \pm 16.5 \mathrm{mg} \mathrm{kg}^{-1}$ in BLCS to $15.2 \pm 2.7 \mathrm{mg} \mathrm{kg}^{-1}$ in RCS. In the three calcareous soils, the stable organic $\mathrm{C}$ ranging from $7.20-138 \mathrm{~g} \mathrm{~kg}^{-1}$ soil, accounted for average $54.9 \pm 13.7 \%$ of the initial organic $C$ (Table S3). The MOC accounted for $29.9-57.5 \%$ of the stable organic $C$, with a mean value of $43.1 \pm 10.2 \%$. The ROC content varied widely among three calcareous soils ranged from $3.08 \mathrm{~g} \mathrm{~kg}^{-1}$ in RCS to $59.0 \mathrm{~g} \mathrm{~kg}^{-1}$ in BLCS, accounting for $56.9 \pm 11.1 \%$ of stable OC.

From BLCS evolved through BRCS to RCS, DOC, MOC, and ROC contents decreased significantly (Figure 3). However, Alkyl C, O-alkyl C, Aromatic C, or Carbonyl C had no significant difference among three calcareous soils (Figure 4). 

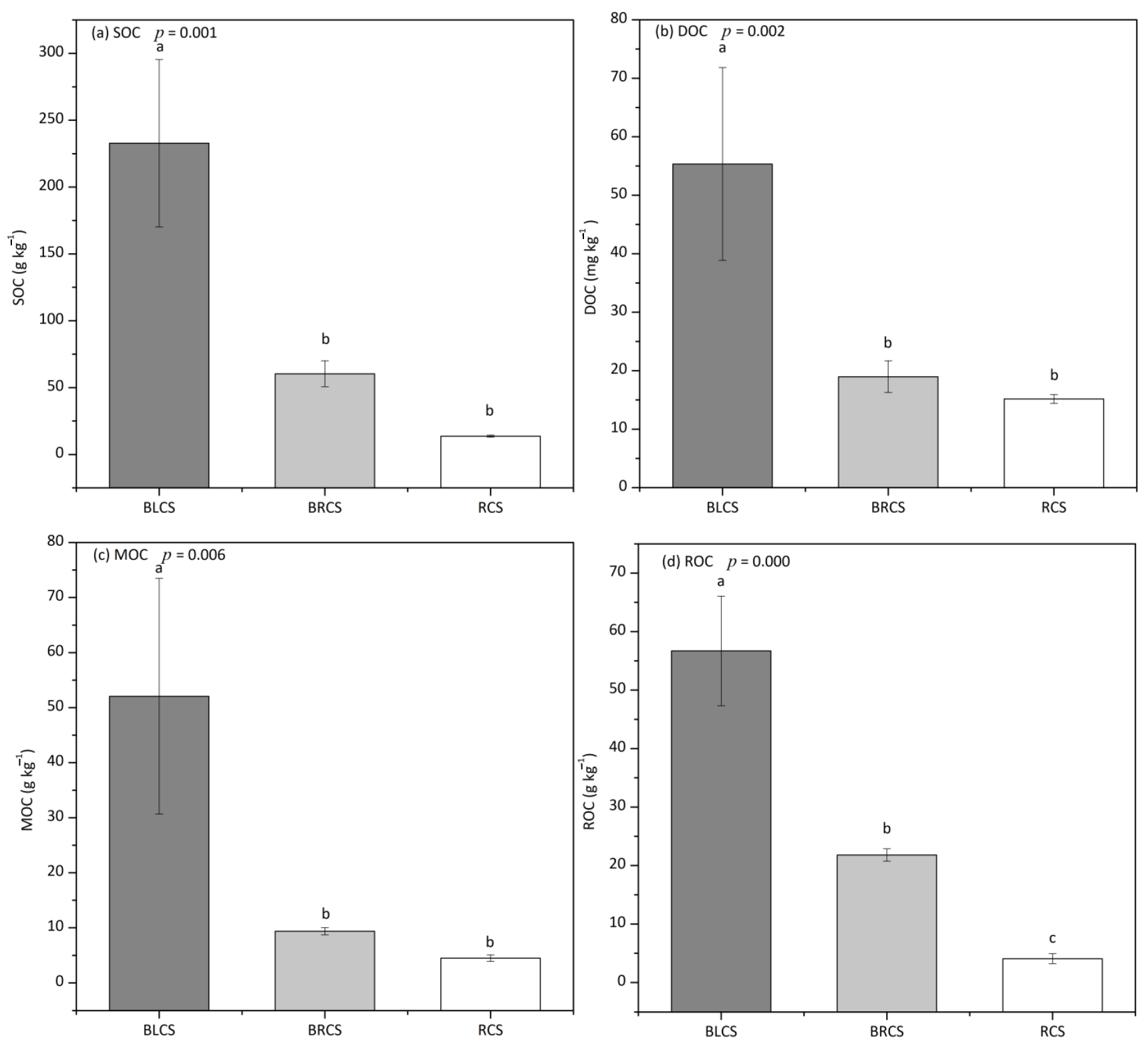

Figure 3. Different fractions of soil organic carbon (SOC) in the subtropical karst area of southwest China. (a) SOC in bulk soil; (b) SOC in dissolved organic carbon (DOC); (c) SOC in mineral protected organic carbon (MOC) or MOC per gram bulk soil; (d) SOC in recalcitrant organic carbon (ROC) or ROC per gram bulk soil. Values are means with standard error (SE), $n=3$. Different lowercase letters denote significant difference at $p<0.05$ level among different calcareous soils. 

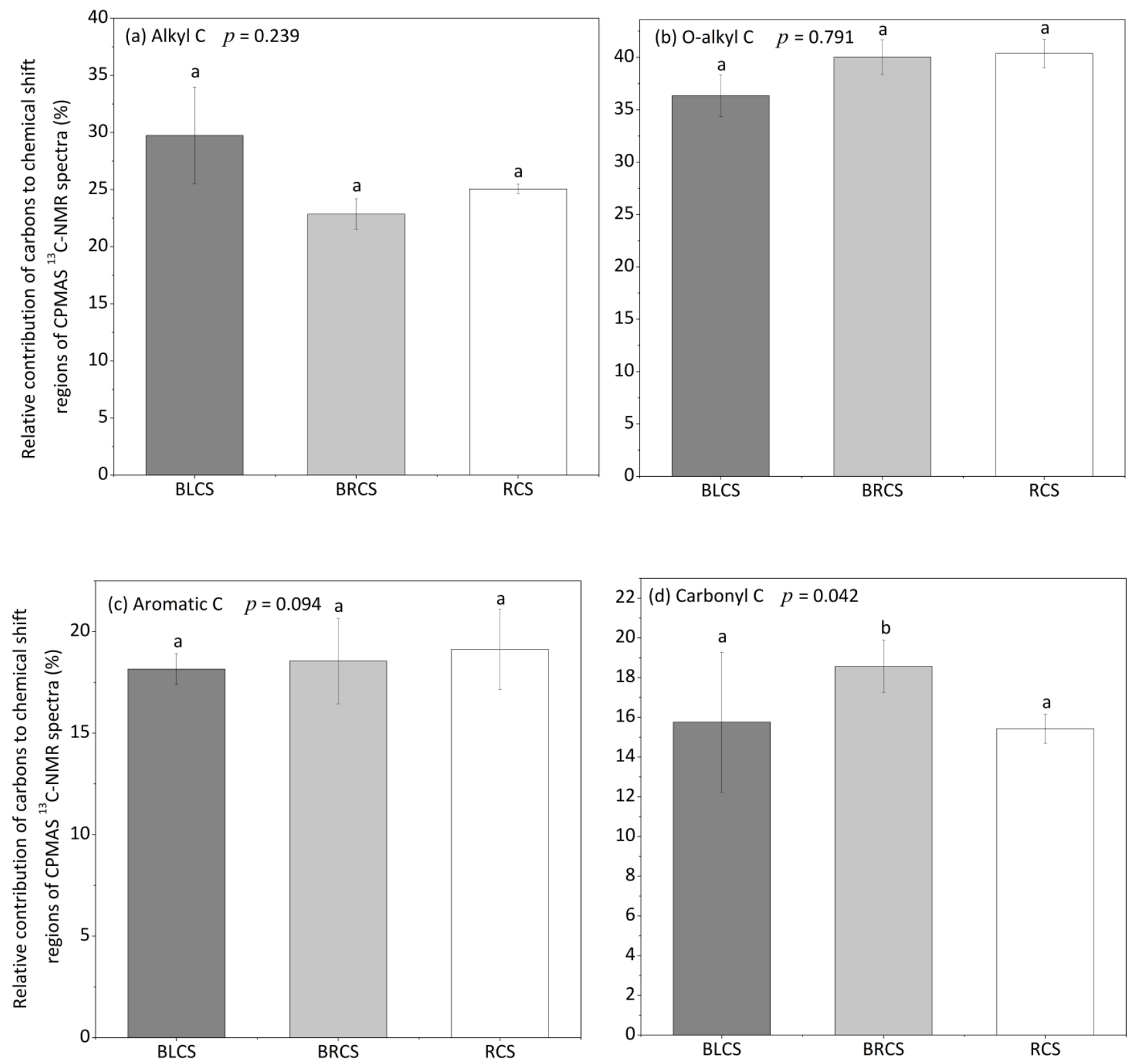

Figure 4. Relative contribution of carbons to chemical shift regions of CPMAS ${ }^{13} \mathrm{C}-\mathrm{NMR}$ spectra. (a) Alkyl C in chemical shift regions of CPMAS ${ }^{13} \mathrm{C}-\mathrm{NMR}$ spectra; (b) O-alkyl C chemical shift regions of CPMAS ${ }^{13} \mathrm{C}-\mathrm{NMR}$ spectra; (c) Aromatic C chemical shift regions of CPMAS ${ }^{13} \mathrm{C}-\mathrm{NMR}$ spectra; (d) Carbonyl C chemical shift regions of CPMAS ${ }^{13} \mathrm{C}-\mathrm{NMR}$ spectra.

\section{Discussion}

In this study, although bulk soil $\mathrm{pH}$, the relative contribution of carbons to chemical shift regions of CPMAS ${ }^{13} \mathrm{C}-\mathrm{NMR}$ spectra, and F:B ratio did not significantly change with the evolvement of calcareous soil, the contents of SOC and related soil fractions significantly decreased, indicating that the responses of SOC fractions to calcareous soil evolvement were likely related with the differences in physico-chemical protection between these fractions and the various factors (e.g., base cations, microbial community, etc.). However, the chemical composition of organic C (i.e., Alkyl C, O-alkyl C, Aromatic C, and Carbonyl C) had no significant difference among three calcareous soils. This suggests that the chemical structure of each organic carbon maintains at a relative equilibrium state. The decrease of organic carbon content from BLCS, BRCS, to RCS is a process of synergistic decrease of each component. 


\subsection{The Changes in Microbial Community Composition during the Evolvement of Calcareous Soil}

Our data found that calcareous soil evolvement had a substantially negative effect on total PLFA, bacteria (i.e., GP and GN), fungi, and actinomycetes, supporting our second hypothesis. Two potential reasons can explain why the abundance of microbial community decreased with the evolvement of calcareous soil. First, the bacterial community exhibited as disparate among calcareous soils with the leaching of $\mathrm{Ca}^{2+}$ and $\mathrm{Mg}^{2+}$ with the evolvement of calcareous soil [40]. Second, physicochemical characteristics are strongly linked to bacterial communities [41]. For example, water retention capacity greatly changes the oxygen diffusion in soil pores, and then affects microbial activity. In this study, from BLCS to RCS through BRCS, soil water holding capacity decreased significantly, and positively related with the abundances of total PLFA, bacteria, fungi, and actinomycetes (Figure S4), supporting the important role of soil water in microbial growth. The F:B ratio had no significant differences among three calcareous soils, which may be attributed to non-significant change in $\mathrm{pH}$. The previous studies found the fungal:bacterial ratio was mainly affected by soil $\mathrm{pH}[40,42]$. In this study, $\mathrm{pH}$ value was in the range of neutral to alkaline (7.01-7.25) and there was no significant difference among three calcareous soils. These results suggest that the bacteria and fungi decrease possibly at the same proportion as the evolvement of calcareous soil.

\subsection{The Changes in Various SOC Fraction during the Evolvement of Calcareous Soil}

Results from our study showed that various SOC fractions (e.g., SOC, DOC, MOC, and ROC, etc.) decreased from BLCS to RCS through BRCS, which was consistent with our first hypothesis. Two possible reasons were proposed to explain this finding. First, results from the correlation analysis showed the significant correlation between SOC fractions (SOC, DOC, MOC, and ROC) and soil base cations $\left(\mathrm{Ca}_{\mathrm{ex}}, \mathrm{Fe}_{\mathrm{ex}}\right.$, and $\left.\mathrm{Al}_{\mathrm{ex}}\right)$ (Figure 5). This indicates that mineral composition plays an important role in the stability of organic carbon. This is consistent with the previous research results, e.g., complexation of organic ligand by free $\mathrm{Ca}^{2+}, \mathrm{Al}^{3+}, \mathrm{Fe}^{3+}$ and their mineral forms polyvalent cation bond bridges, and the adsorption of SOC to minerals bound by ligand exchange $[15,24,25]$, etc. In addition to $\mathrm{Fe}$ and $\mathrm{Al}$ oxides, $\mathrm{Ca}^{2+}$ can also constrain SOM availability by forming both inner- and outer-sphere cation bridging [15], and its protective effect can outweigh $\mathrm{Fe} / \mathrm{Al}$ oxides in neutral to alkaline soils. Additionally, these oxides and cations can accelerate the formation of stable aggregates by their cementation of other minerals [43,44], which results in the compartmentalization of substrates from enzymes and restricts the diffusion of oxygen, thus decreasing $\mathrm{SOM}$ decomposition. The present study showed that $\mathrm{Ca}_{\mathrm{ex}}, \mathrm{Fe}_{\mathrm{ex}}$, and $\mathrm{Al}_{\mathrm{ex}}$ reduced with the evolvement of calcareous soils, suggesting that the stabilization of SOC by adsorption to minerals through polyvalent bridging (especially $\mathrm{Ca}^{2+}, \mathrm{Al}^{3+}$, and $\mathrm{Fe}^{3+}$ ) may decline [15,45]. Second, soil microorganism community composition, including PLFA, bacteria, and fungi, was positively correlated to SOC fractions (Figure S5), which could strengthen the opinion that the soil microbial residues as an important source of organic $\mathrm{C}$ input to calcareous soil $\mathrm{C}$ pools. Together, these factors from our results indicated that the loss of SOC fractions may be caused by the combined effect of slowdown of chemical absorption of SOC to minerals through polyvalent under leaching and weathering and microbial $\mathrm{C}$ inputs decrease during the evolvement of calcareous soil. 

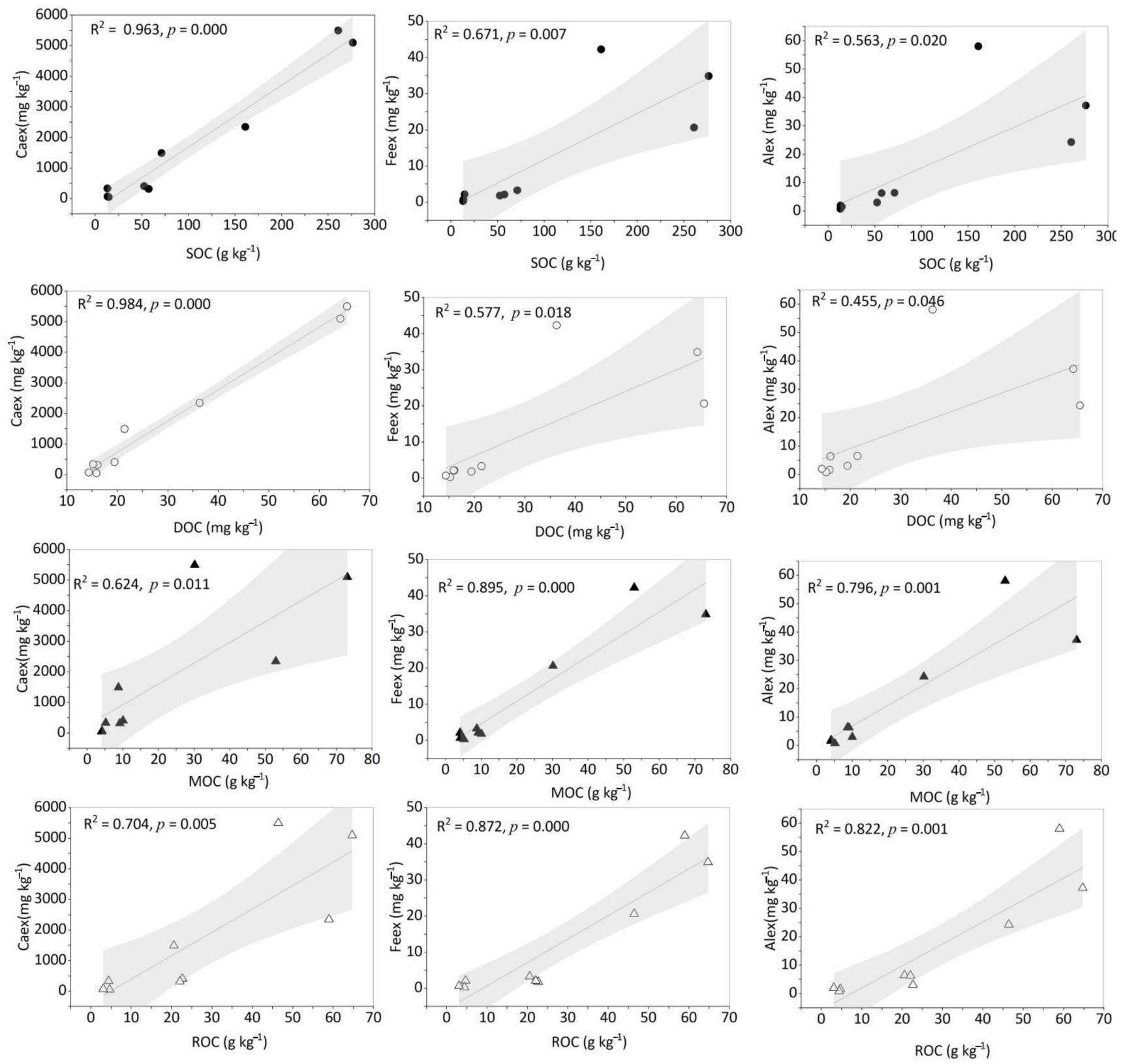

Figure 5. Correlation of fractions of SOC with base cation in the subtropical karst area of southern $\mathrm{China} \mathrm{Ca}_{\mathrm{ex}}, \mathrm{Fe}_{\mathrm{ex}}$, and $\mathrm{Al}_{\text {ex }}$ represents exchangeable $\mathrm{Ca}, \mathrm{Fe}$, and $\mathrm{Al}$, respectively.

\section{Conclusions}

Our study emphasized the susceptibility of SOC pools to soil evolvement, however, soil evolvement did not change the relative contribution of carbons to chemical shift regions of CPMAS ${ }^{13} \mathrm{C}-\mathrm{NMR}$ spectra and F:B ratio in the karst region. Moreover, our study clearly showed that the important role of extractable cations (e.g., extractable $\mathrm{Ca}^{2+}, \mathrm{Al}^{3+}$, and $\mathrm{Fe}^{3+}$ ) in affecting soil C storage. Taken together, on the one hand, the stability of SOC in the karst area accords with some mechanisms of previous studies (e.g., microbial composition and soil geochemistry), on the other hand, it has its own unique characteristics (e.g., the relative contribution of carbons to chemical shift regions of CPMAS ${ }^{13} \mathrm{C}-\mathrm{NMR}$ spectra and F:B ratio). In the future research, combining these features could be better for understanding and predicting the soil $\mathrm{C}$ dynamics in karst areas. This result provides expanded guidance on the practice of ecological restoration in karst rocky desertification regions. 
Supplementary Materials: The following are available online at https:/ /www.mdpi.com/1999-490 7/12/2/221/s1, Figure S1: Effects of different calcareous soils on the abundance of soil microbial groups (indicated by PLFA) in the subtropical evergreen broadleaved forest of southwest of China. Figure S2: Principal component analysis (PCA) of microbial phospholipid fatty acids (PLFAs, vectors with different color lines). Figure S3: Principal component analysis (PCA) of extractable cations (vectors with different color lines). Figure S4: Correlation of microbial phospholipid fatty acids with water holding capacity in the subtropical karst area of southwest China. Figure S5: Correlation of SOC fractions with microbial phospholipid fatty acids in the subtropical karst area of southwest China. Table S1: Basic information of the study area and sampling sites. Table S2: The phospholipid fatty acids detected in this study (Chen et al., 2020). Table S3. Total organic C (OC), nitrogen (N), and $\mathrm{C} / \mathrm{N}$ ratios of $\mathrm{OM}$ fractions.

Author Contributions: Conceptualization, T.Z. and H.Y.; methodology, H.Y.; investigation, Y.X.; writing—original draft preparation, H.Y.; writing—review and editing, T.Z.; experiments—M.Z. All authors have read and agreed to the published version of the manuscript.

Funding: This study was funded by the Natural Scientific Foundation of Guangxi Zhuang Autonomous Region of China under Grant No. 2017GXNSFAA198153 and GuikeAD19245176, Natural Scientific Foundation under Grant No. 41702281, and the Special Fund for Basic Scientific Research of Institute of Karst Geology, CAGS (No. 2020004), the Guilin Scientific Research and Technology Development Project (No. 20180101-3).

Institutional Review Board Statement: Not applicable.

Informed Consent Statement: Not applicable.

Data Availability Statement: The data presented in this study are available on request from the corresponding author. The data are not publicly available due to privacy.

Conflicts of Interest: The authors declare that they have no known competing financial interest or personal relationships that could have appeared to influence the work reported in this paper.

\section{References}

1. Wang, J.; Xu, Y.; Ding, F.; Gao, X.; Li, S.; Sun, L.; An, T.; Pei, J.; Li, M.; Wang, Y.; et al. Process of plant residue transforming into soil organic matter and mechanism of its stabilization: A review. Acta Pedol. Sin. 2019, 56, 528-540. (In Chinese)

2. Yang, Y.; Tilman, D.; Furey, G.; Lehman, C. Soil carbon sequestration accelerated by restoration of grassland biodiversity. Nat. Commun. 2019, 10, 718. [CrossRef] [PubMed]

3. Cotrufo, M.; Ranalli, M.; Haddix, M.; Six, J.; Lugato, E. Soil carbon storage informed by particulate and mineral-associated organic matter. Nat. Geosci. 2019, 12, 989-994. [CrossRef]

4. Gentsch, N.; Wild, B.; Mikutta, R.; Capek, P.; Diakova, K.; Schrumpf, M.; Turner, S.; Minnich, C.; Schaarschmidt, F.; Shibistova, O.; et al. Temperature response of permafrost soil carbon is attenuated by mineral protection. Glob. Chang. Biol. 2018, 24, 3401-3415. [CrossRef]

5. Xu, J.; Gao, L.; Sun, Y.; Cui, X. Distribution of mineral-bonded organic carbon and black carbon in forest soils of great Xing'an mountains, China and carbon sequestration potential of the soils. Acta Pedol. Sin. 2018, 55, 236-246. (In Chinese)

6. Ye, C.; Hall, S.; Hu, S. Controls on mineral-associated organic matter formation in a degraded Oxisol. Geoderma 2019, 338, 383-392. [CrossRef]

7. Wei, X.; Deng, X.; Xiang, W.; Lei, P.; Ouyang, S.; Wen, H.; Chen, L. Calcium content and high calcium adaptation of plants in karst areas of southwestern Hunan, China. Biogeosciences 2018, 15, 2991-3002. [CrossRef]

8. Jiang, Z.; Lian, Y.; Qin, X. Rocky desertification in Southwest China: Impacts, causes, and restoration. Earth-Sci. Rev. 2014, 132, 1-12. [CrossRef]

9. Cao, J.; Yang, H.; Kang, Z. Preliminary regional estimation of carbon sink flux by carbonate rock corrosion: A case study of the Pearl River Basin. Chin. Sci. Bull. 2011, 56, 3766-3773. [CrossRef]

10. Wu, L. Soil Fertilizer Science; China Agricultural Publishing House: Beijing, China, 2004. (In Chinese)

11. Wei, Q.; Chen, H.; Wu, Z.; Huang, Y.; Jiao, J. The geochemical characteristics of limestome soils in Longgang area, Guangxi. Acta Pedol. Sin. 1983, 20, 30-42.

12. Yang, H.; Prelovsek, M.; Huang, F.; Zhang, C.; Cao, J.; Ravbar, N. Quantifcation and evaluation of soil organic carbon and its fractions: Case study from the Classical Karst, SW Slovenia. Acta Carsologica. 2019, 48, 295-311. [CrossRef]

13. Huang, C. Soil Science; China Agricultural Publishing House: Beijing, China, 2000. (In Chinese)

14. Yang, H.; Zhang, P.; Zhu, T.; Li, Q.; Cao, J. The characteristics of soil C, N, and P stoichiometric ratios as affected by geological background in a karst graben area, Southwest China. Forests 2019, 10, 601. [CrossRef] 
15. Rowley, M.C.; Grand, S.; Verrecchia, E.P. Calcium-mediated stabilisation of soil organic carbon. Biogeochemistry 2018, 137, 27-49. [CrossRef]

16. Yang, S.; Cammeraat, E.; Jansen, B.; Cerli, C.; Kalbitz, K. Organic carbon stabilization of soils formed on acidic and calcareous bedrocks in Neotropical Alpine grassland, Peru. EGU Gen. Assem. 2016, 18, EGU2016-2646.

17. Whittinghill, K.A.; Hobbie, S.E. Effects of $\mathrm{pH}$ and calcium on soil organic matter dynamics in Alaskan tundra. Biogeochemistry 2012, 111, 569-581. [CrossRef]

18. Dungait, J.A.J.; Hopkins, D.W.; Gregory, A.S.; Whitmore, A.P. Soil organic matter turnover is governed by accessibility not recalcitrance. Glob. Chang. Biol. 2012, 18, 1781-1796. [CrossRef]

19. Chen, L.; Liang, J.; Qin, S.; Liu, L.; Fang, K.; Xu, Y.; Ding, J.; Li, F.; Luo, Y.; Yang, Y. Determinants of carbon release from the active layer and permafrost deposits on the Tibetan Plateau. Nat. Commun. 2016, 7, 13046. [CrossRef] [PubMed]

20. McLauchlan, K.K.; Hobbie, S.E. Comparison of labile soil organic matter fractionation techniques. Soil Sci. Soc. Am. J. 2004, 68, 1616-1625. [CrossRef]

21. Liu, X.; Li, L.; Qi, Z.; Han, J.; Zhu, Y. Land-use impacts on profile distribution of labile and recalcitrant carbon in the Ili River Valley, northwest China. Sci. Total Environ. 2017, 586, 1038-1045. [CrossRef] [PubMed]

22. Wan, D.; Ye, T.; Lu, Y.; Chen, W.; Cai, P.; Huang, Q. Iron oxides selectively stabilize plant-derived polysaccharides and aliphatic compounds in agricultural soils. Eur. J. Soil Sci. 2019, 70, 1153-1163. [CrossRef]

23. Zong, M.; Lin, C.; Li, S.; Li, H.; Duan, C.; Peng, C.; Guo, Y.; An, R. Tillage activates iron to prevent soil organic carbon loss following forest conversion to cornfields in tropical acidic red soils. Sci. Total Environ. 2020, 761, 143253. [CrossRef]

24. Schneider, M.P.W.; Scheel, T.; Mikutta, R.; Van, H.; Kaiser, K.; Kalbitz, K. Sorptive stabilization of organic matter by amorphous Al hydroxide. Geochim Cosmochim Acta 2010, 74, 1606-1619. [CrossRef]

25. Jilling, A.; Keiluweit, M.; Contosta, A.R.; Frey, S.; Schimel, J.; Schnecker, J.; Smith, R.G.; Tiemann, L.; Grandy, A.S. Minerals in the rhizosphere: Overlooked mediators of soil nitrogen availability to plants and microbes. Biogeochemistry 2018, 139, 103-122. [CrossRef]

26. Guangxi Soil and Fertilizer Workstation; Guangxi Science and Technology Press: Nanning, China, 1994. (In Chinese)

27. Bardgett, R.D.; Freeman, C.; Ostle, N.J. Microbial contributions to climate change through carbon cycle feedbacks. ISME J. 2008, 2, 805-814. [CrossRef]

28. Grover, M.; Maheswari, M.; Desai, S.; Gopinath, K.A.; Venkateswarlu, B. Elevated $\mathrm{CO}_{2}$ : Plant associated microorganisms and carbon sequestration. Appl. Soil Ecol. 2015, 95, 73-85. [CrossRef]

29. Xie, Y.; Yang, L.; Zhu, T.; Yang, H.; Zhang, J.; Yang, J.; Cao, J.; Bai, B.; Jiang, Z.; Liang, Y.; et al. Rapid recovery of nitrogen retention capacity in a subtropical acidic soil following afforestation. Soil Biol. Biochem. 2018, 120, 171-180. [CrossRef]

30. IUSS Working Group. WRB World Reference Base for Soil Resources 2014. International Soil Classification System for Naming Soils and Creating Legends for Soil Maps; World Soil Resources Reports No. 106; FAO: Rome, Italy, 2014.

31. Ding, J.; Li, F.; Yang, G.; Chen, L.; Zhang, B.; Liu, L.; Fang, K.; Qin, S.; Chen, Y.; Peng, Y.; et al. The permafrost carbon inventory on the Tibetan Plateau: A new evaluation using deep sediment cores. Glob. Chang. Biol. 2016, 22, 2688-2701. [CrossRef]

32. Ross, D.S.; Ketterings, Q. Recommended methods for determining soil cation exchange capacity. Recomm. Soil Test. Proced. Northeast. United States 1995, 2, 75-86.

33. Aguilera, N.H.; Jackson, M.L. Iron Oxide Removal from Soils and Clays. Soil Sci. Soc. Am. J. 1953, 17, 359-364. [CrossRef]

34. Kleber, M.; Mikutta, R.; Torn, M.S.; Jahn, R. Poorly crystalline mineral phases protect organic matter in acid subsoil horizons. Eur. J. Soil Sci. 2005, 56, 717-725. [CrossRef]

35. Mikutta, R.; Kleber, M.; Torn, M.S.; Jahn, R. Stabilization of Soil Organic Matter: Association with Minerals or Chemical Recalcitrance? Biogeochemistry 2006, 77, 25-56. [CrossRef]

36. Wagai, R.; Kishimoto-Mo, A.W.; Yonemura, S.; Shirato, Y.; Hiradate, S.; Yagasaki, Y. Linking temperature sensitivity of soil organic matter decomposition to its molecular structure, accessibility, and microbial physiology. Glob. Chang. Biol. 2013, 19, 1114-1125. [CrossRef]

37. Bossio, D.A.; Scow, K.M. Impacts of Carbon and Flooding on Soil Microbial Communities: Phospholipid Fatty Acid Profiles and Substrate Utilization Patterns. Microb. Ecol. 1998, 35, 265-278. [CrossRef]

38. Frostegard, A.; Tunlid, A.; Baath, E. Use and misuse of PLFA measurements in soils. Soil Biol. Biochem. 2011, 43, 1621-1625. [CrossRef]

39. Chen, X.; Ding, Z.; Tang, M.; Zhu, B. Greater variations of rhizosphere effects within mycorrhizal group than between mycorrhizal group in a temperate forest. Soil Biol. Biochem. 2018, 126, 237-246. [CrossRef]

40. Chen, J.; Xiao, W.; Zheng, C.; Zhu, B. Nitrogen addition has contrasting effects on particulate and mineral-associated soil organic carbon in a subtropical forest. Soil Biol. Biochem. 2020, 142, 107708. [CrossRef]

41. Yan, B.; Sun, L.; Li, J.; Liang, C.; Wei, F.; Xue, S.; Wang, G. Change in composition and potential functional genes of soil bacterial and fungal communities with secondary succession in Quercus liaotungensis forests of the Loess Plateau, western China. Geoderma 2020, 364, 114199. [CrossRef]

42. Rousk, J.; Brookes, P.C.; Baath, E. Contrasting Soil pH Effects on Fungal and Bacterial Growth Suggest Functional Redundancy in Carbon Mineralization. Appl. Environ. Microbiol. 2009, 75, 1589-1596. [CrossRef] [PubMed]

43. Barral, M.T.; Arias, M.; Guérif, J. Effects of iron and organicmatter on the porosity and structural stability of soil aggregates. Soil Till. Res. 1998, 46, 261-272. [CrossRef] 
44. Wang, L.Y.; Qin, L.; Lü, X.G.; Jiang, M.; Zou, Y.C. Progress in researches on effect of iron promoting accumulation of soil. Acta Pedol. Sin. 2018, 55, 1041-1050. (In Chinese)

45. Rasmussen, C.; Heckman, K.; Wieder, W.R.; Keiluweit, M.; Lawrence, C.R.; Berhe, A.A.; Blankinship, J.C.; Crow, S.E.; Druhan, J.L.; Hicks, P.C.E.; et al. Beyond clay: Towards an improved set of variables for predicting soil organic matter content. Biogeochemistry 2018, 137, 297-306. [CrossRef] 